\title{
Can African Countries Attract Investments without Bilateral Investment Treaties? The Ghanaian Case
}

\author{
Dominic Npoanlari Dagbanja \\ Law School, University of Western Australia \\ dominic.dagbanja@uwa.edu.au
}

\begin{abstract}
Can bilateral investment treaties (BITs) play any singular or distinctive role in attracting foreign direct investment (FDI) to African countries? This article analyses data on FDI flows to Ghana from countries with which it is a party in BITs and those with which it is not. The main finding is that most FDIs in Ghana come from countries with which it does not have BITs, meaning in effect that investments can be attracted without BITs. It also means that BITs do not play any statistically significant role in attracting FDI from Ghana's contracting parties to BITs when compared to FDI inflows to Ghana from other countries. This evidence refutes the role of FDI attraction conventionally attributed to BITs. Based on the data analysed, BITs are not uniquely relevant for investment attraction to Ghana and, by extension, similarly placed African countries, which thus need to rethink both the importance they attach to BITs and whether FDI could be regulated based solely on municipal investment law.
\end{abstract}

\section{Introduction}

According to the United Nations Conference on Trade and Development

Investment treaty making has reached a turning point. The number of new international investment agreements (IIAs) concluded in 2017 (18) was the lowest since 1983. Moreover, for the first time, the number of effective treaty terminations outpaced the number of new IIAs. In contrast, negotiations for megaregional agreements maintained momentum, especially in Africa and Asia (UNCTAD 2018, p. xiii).

The decline in the making of IIAs or investment treaties and a simultaneous increase in the termination of IIAs point to a rejection of the 
IIA regime to some extent. The decline in the making of IIAs and the increase of terminations are not surprising considering the limitations they place on the right to regulate in the public interest and the increasing backlash against investment treaty law and arbitration (Dagbanja 2015; Sornarajah 2010; Waibel et al. 2010; Harten 2007). Foreign investors have won $60 \%$ of the decided investor-state disputes (United Nations Conference on Trade and Development [UNCTAD], 2018, p. xiii).

The BITs are premised on the conventional argument that foreign investment leads to development and that BITs lead to the attraction of FDI necessary for development. For countries in 'transition,' BITs 'may provide a shortcut to policy credibility in the international arena' (Rose-Ackerman \& Tobin 2009, p. 132). In order to reap the supposed benefits of BITs and investor-state arbitration, developing countries governments sign BITs with developed countries (Rose-Ackerman and Tobin 2009). Yet, according to M. Sornarajah (2010 p. 299), the theory that foreign investment leads to development and that investment treaties attract foreign investment is contestable because there is no evidence,

to show that investment treaties have led to greater inflows of foreign investment into states making them. Many states, particularly the least developed states, have liberalised their foreign investment laws and made large number of investment treaties without witnessing the expected flows of foreign investment ... Since the underlying assumption of these treaties is that flows of foreign investment leads to development, there is no reference to economic development in the treaties nor do they contain any meaningful provisions as to the promotion of such economic development.

The literature on the link between BITs and investment flows is variable and inconclusive (Swenson 2009). Hallward-Driemeier (2009), for example, carried out a study which concluded that BITs do not serve to attract additional foreign investment and that, while BITs can reinforce the quality of institutions, there was little evidence that they can serve as substitutes for weak domestic institutions (p. 368). The net impact of BITs 'remains insignificant or negative for the majority of countries. It is only those countries with the strongest domestic institutions that are shown to benefit, albeit slightly, from a BIT' (p. 374). Yackee (2009) is similarly of the opinion that BITs 'are statistically significant predicators of FDI share only for low-risk countries, and where the magnitude of that effect 
increases as risk decreases. The problem is that there is very little theoretical reason to expect BITs to only be effective in low-risk situations, or to become more effective as risk decreases' (p. 391). Yackee (2008), based on statistical analysis, did not find a link between investment treaty protections and FDI. Based on interviews and existing literature, Poulsen (2010) found that multinational business entities hardly consider BITs when making the decision to invest abroad. Asiedu (2002) argued that policies that have been successful in attracting FDI elsewhere may not be successful in Africa, suggesting the factors that attract FDI are not constant and do not play the same role in each environment. However, other scholars have found that BITs lead to FDI attraction (Egger \& Pfaffermayer 2004; Neumayer \& Spess 2005; Salacuse \& Sullivan 2005; Aisbett 2009; Buthe \& Milner 2009; Kerner 2009; Berger et al. 2013).

In view of the conflicting literature on the subject and the legal and policy costs associated with BITs such as investment treaty arbitration expenses resulting from arbitral suits and the limiting effects of BITs on the right to regulate in the public interest (Sornarajah 2010; Kelsey 2012; Kelsey 2010; Harten 2008; Schneiderman 2008), each country has to assess the actual role of these treaties as determinants of its FDI flows. Such an examination is necessary for each country to decide the importance to attach to BITs in view of their legal and policy costs. Moreover, as evidenced by the work of Asiedu (2002) showing that different factors may attract investment in different environments, it would be misleading for a country to rely on the general theory of the role of BITs in investment attraction and development without making an assessment of country-specific situations that may be an incentive to invest or to not invest in the country involved.

Accordingly, this article is based on empirical data that speak to the reality of investment inflows to and out of Ghana. The research question on the subject of BITs and FDI has always been put in terms of whether BITs attract investments. The question this research seeks to address is whether a country such as Ghana can attract investments from countries with which it does not have BITs. Does the sole fact that Ghana is a party to investment treaties lead to more investment attraction from its BIT partners in comparison with non-BIT partners? This assessment is done by reviewing and interpreting reports on investment inflows to and out of Ghana and is based on existing scholarship on the determinants of foreign investment in Ghana. It is based on the Ghana Investment Promotion Centre quarterly reports on investment inflows to Ghana and on UNCTAD world investment 
reports. The approach adopted by this study is justified because existing methodologies on the subject have failed to help determine with certainty whether BITs do directly contribute to increasing investment flows in country-specific cases. On this issue of the efficacy of existing research on investment flows, the Economic Commission for Africa has rightly stated that, despite many African countries continuing to sign BITs among themselves or with the rest of the world,

the debate continues. The methodological approaches of these empirical studies differ, such as the choice of the dependent variable, sample size, dyadic versus non-dyadic model, and estimation techniques. Thus it is perhaps unsurprising that this literature does not offer a clear answer. One could hypothesize additional reasons for such lack of clarity in research based on econometric methods: for instance, existing studies generally treat BITs as identical or ... largely homogeneous (2016, pp. 10$11)$.

Not all such statistical and theoretical models always deal with real practical issues specific to specific situations. As stated by Yackee:

[I]f we really want to prove that BITs do or do not matter, that they do or do not work as advertised, then we may want to consider whether or large- $n$ statistical studies of aggregate FDI flows are the best means of empirically addressing the question. One potentially promising solution is to return to less modern methodologies, in particular in-depth case study or survey instruments (2009, p. 391).

Existing literature is hardly helpful to individual countries in making decisions on the actual role of BITs as sources of investment flows within national territories because the literature does not speak to country-specific situations. As stated, the whole foundation of BITs is that they attract foreign investment. Therefore, if it can be established that BITs do not attract foreign investment or that their role in investment attraction is insignificant, then states might not be signing BITs at all or might approach them with much less deference and attention than they currently do. Thus, ascertaining the relationship between BITs and investment flows is very important and should be the foundation for any decision to sign on to these instruments. 
It is in the very nature of BITs to limit states' right to regulate in the public interest. In fact, countries such as Bolivia and Ecuador have withdrawn from the Convention on the Settlement of Investment Disputes between States and Nationals of Other States of 1966 because of concerns that they limit their sovereignty, while Argentina has been struggling to pay compensations arising from arbitral awards made under the investor-state dispute settlement mechanisms. Following a review of the actual value of investment treaties for investment inflows to South Africa and an assessment of the risk ISDS poses to the adoption of policies and domestic interventionist measures, South Africa has terminated about thirteen investment treaties with other countries (Feris 2015). The South African Government also enacted the Protection of Investment Act 2015 to regulate the protection and promotion of investments domestically.

It follows that if the tradeoffs for entering into BITs and limiting sovereign right to regulate cannot be established with precision or reasonable certainty, then states would have to reconsider whether they should be entering into BITs at all. The making of such a decision depends on relevant knowledge about BITs and investment attraction. Direct and country-related studies such as this one are, therefore, very relevant.

Ghana has signed twenty-eight BITs, nine of which have entered into force. Ghana's BITs in force with Burkina Faso, China, Denmark, Germany, Malaysia, Netherlands, Serbia, Switzerland and the United Kingdom were founded on the idea that they were necessary to create favourable conditions for investments so as to stimulate the flow of investments and business initiative, capital and technology transfers and development (Dagbanja 2015).

The review and analysis lead to the conclusion that the signing of BITs by Ghana has not advantaged it in terms of investment attraction from its contracting parties to BITs in comparison with its attraction of investment from countries with which it is not a party, both in terms of the value and quantity of investment attracted. This supports the proposition that the fact that two countries are parties to a BIT does not mean that investors from the countries will make investments in the respective territories solely based on the availability of investment treaty protection. Nothing from the study suggests that investors from countries with which Ghana has BITs invested merely because Ghana is a party to BITs with their home countries. There is, however, evidence to show that most of the investments Ghana received both in terms of projects and the value of investments have come from countries with which Ghana is not a party. 
The conclusion to draw from this finding is that BITs do not play any remarkable or outstanding role in investment attraction in comparison with all other factors in Ghana. The study raises reasonable doubt as to the necessity of BITs and thus cautions against overreliance and overconfidence in them in terms of their supposed role in investment attraction in Ghana. The study also leads to the conclusion that a country can attract FDI from countries with which it does not have BITs. Thus, Ghana must place emphasis on factors other than BITs such as domestic legislation and policy in its search for FDI.

\section{Motivations for FDI}

The motivations for foreign investment are explained by various theories such as the capital arbitrage theory, portfolio diversification theory, market imperfection hypothesis, intangible assets hypothesis, industrial organisation theory, and internalisation theory (Yelpaala 1984; 1985).

Capital arbitrage theory argues that international capital mobility is explicable by interest rate differentials. Thus, an investor seeks to maximise the returns on capital by investing in countries where interest rates are higher. Portfolio diversification theory posits that multinational enterprises are interested in both the highest rate of returns on their investments and the overall stability of these earnings. Rate of return then is crucial in the decision to locate an investment in a particular country or region (Yelpaala 1984). The market imperfection hypothesis holds that multinational enterprises with intangible assets cannot dispose or license them efficiently in conventional markets because of factors related to the infirmities of the assets. For example, a question arises as to the appropriate rental price of obsolete technology to a licensee in a developing country, whether the rental price should be determined by its market value in the home market, in which it is obsolete, or in the host country. In this circumstance and related contract law problems, profit-maximising owners of technology would prefer to invest in their use abroad. The intangible assets theory assumes that intangible assets constitute legally protectable property with universally recognised attributes, and that adequate protection of these assets requires some participation by host countries in multilateral, bilateral, or regional conventions and treaties to recognise and protect industrial property rights similar to those enjoyed in the home country. This approach justifies the conclusion of BITs. Industrial organisation theory explains FDI in terms of oligopolistic market structures; oligopoly with differentiated products based on technology protected by patents, or advertising protected by registered trademarks and brand names, goes to the very root of FDI process in horizontal and vertical investments. 
Finally, internationalisation involves bringing under the same ownership and control the same business activities linked together by markets. The basic motivation for internationalisation is efficiency; internationalisation allows businesses to coordinate various aspects of their activities through a set of efficient external markets. Thus, internationalisation across national boundaries explains foreign production, sales and other operations (Yelpaala 1985).

Corporate motives behind foreign investment can also be appreciated by looking at the various types of international investment, including natural resource seeking, market seeking, efficiency seeking, and strategic assets seeking investment. Natural resource seeking international investment is based on locational factors whereby investors invest in a particular region or country depending on its natural resource endowments. Market seeking investment aims to supply a significant foreign market through local production or service provision that replaces importation. Efficiency seeking investment is concerned with enhancing the firm's competitiveness by allowing for a more cost-effective cross-border integration of production. This may be low wages or knowledge driven. Finally, strategic assets seeking investment seeks to enhance competitiveness by accessing knowledge based assets of the investment location. The goal is to tap into the local innovation system and thereby enhance the foreign investor's technological efficiency and may be achieved through acquisition of or alliance with local firms (Muchlinski 2007, p. 32).

Muchlinski articulated the policy and legal considerations that flow from investment choices by foreign investors, arguing that the way in which multinational enterprises (MNEs) operate requires rethinking of what an MNE is (Muchlinski 2007, p. 32). His view is that it may no longer be possible to understand the future development of MNEs by reference to existing theories, which in the main focus on the initial decision by the firm to enter a foreign market through direct investment; rather, it is necessary to see the MNE as a business entity which can take a multiplicity of forms, making identification of the precise boundary of the multinational enterprise harder. It requires examination of flexible approaches to business organisation, a greater recognition of the role of entrepreneurship in MNEs, a closer study of cooperative business structures, and consideration of the role of legal factors in shaping and reshaping MNEs (Muchlinski 2007, p. $33)$.

Thus, although the decision to invest abroad is primarily driven by the desire of foreign investors to advance their profit maximisation, the factors that ultimately determine the decision to invest abroad are indeterminate so 
that singling out BITs as the sole determinant of FDI cannot be supported by evidence and theories. There are various reasons underlying the decision of multinational enterprises to invest in a foreign jurisdiction. These reasons may not necessarily be consistent with the host State's interest to advance its development goals through foreign investment promotion and protection using investment treaties.

It is, therefore, imprudent and far too simplistic for policy and lawmakers to design foreign policies and laws focusing only on the need to attract foreign investors without taking into consideration: (1) the independent motivations of foreign investors in choosing to invest in a foreign country; and (2) the strategic relevance of the investment involved for national development. Thus, absolute and unqualified limitations on the right to regulate in the public interest under BITs can lead to the State making significant concessions to attract foreign investors but only to receive little or no benefit in return. In other words, policymakers need to be cautious about making easy and unfounded generalisations about the role of BITs in foreign investment attraction and the role of FDI in development. As Dunning (1994) rightly argues, the effects of foreign investment also depend on the economic and other objectives and policies set and pursued by governments and the alternatives to foreign investment open to governments. Thus, a wholesale expectation of attracting foreign investment through BITs without considering other relevant factors can result in unjustifiable restriction on the right of the host state to regulate.

\section{BITS and FDI Investment Flows in Ghana}

In this Section, I show that most FDIs in Ghana have come from countries with which Ghana has no BITs. It establishes the point that Ghana's BITs have not advantaged it in terms of FDI attraction from countries it has BITs with when compared with countries it is not a contracting party to BITs. The analysis here also helps establish the point that a country can attract FDI even from non-contracting parties to BITs.

The Ghana Investment Promotion Centre (GIPC) available quarterly reports show that in 2008, the total new investments was GH\&3.17 billion (US\$3.19 billion). Three hundred nine (309) projects were registered in that same year with a total estimated value of GH $\not 4.83$ billion (US\$4.89 billion) (GIPC 2009, p. 4). The FDI component of the estimated value of the projects registered during October to December 2008 was GHф199.96 million (US\$199.96 million). While China topped the list of countries with the highest number of projects registered, India ranked highest with the largest value of investments registered during October to December 2008 (GIPC 
2009 , p. 3). Ghana and India did not have, at the time, a BIT in force but the Ghana-China BIT was in force.

In 2009, the total number of investment projects registered was 257 with a total estimated value of GH $\$ 867.98$ million (US\$619.99 million). The top ten investors in Ghana in 2009 were: China with forty-six registered projects; India with thirty-two projects; Lebanon with twenty-three registered projects; Nigeria with twenty-one registered projects; Britain and United States with twelve registered projects each; British Virgin Islands and Italy with seven registered projects each; and Germany and Korea with six registered projects each. Only two out of these ten countries had BITs with Ghana: Britain and China, the other eight countries did not. In other words, most of the investments Ghana received in 2009 came from countries with which Ghana did not have BITs, as was the case in 2008. Again, over the period 2009, South Africa came on top in terms of the estimated value of registered investment of US\$116.92 million, followed by Nigeria with US $\$ 81.25$ million. Although China was on top in terms of the number of registered projects, it was eighth in terms of the estimated value of investment (US\$22.52 million) (GIPC 2010, p. 3). The evidence of the value of investment projects by each country, like the evidence on the number of registered investment projects per country in 2009, shows that most of the capital investment came from countries that did not have BITs with Ghana at the time the investments were made.

The results of investment inflows in 2010 follow a similar pattern as in 2008 and 2009 in terms of investment inflows from Ghana's contracting parties and non-contracting parties to BITs. In 2010, the total number of projects registered was 385 with a total estimated value of $\mathrm{GH} \phi 1.79$ billion (US\$1.279 billion). Two hundred and forty-nine (249) of the projects were wholly-owned foreign enterprises while 136 were joint ventures between Ghanaians and foreign investors. The joint venture projects were valued at GH $₫ 163.91$ million (US\$117.08 million), and the wholly-owned foreign enterprises were valued at GH $\not 1.63$ billion (US $\$ 1.17$ billion). The FDI component of the estimated value of the projects registered amounted to GH $\notin 1.55$ billion (US\$1.11 billion). Similarly, in 2009, it suggests that wholly-owned enterprises by foreigners tend to dominate the economy both in terms of the number of projects and the capital they bring in. China, which had sixty-seven projects, topped the list of countries with the highest number of projects while Bermuda, with US\$300 million investments, topped the list of countries with the largest value of investments registered in the year (GIPC 2011, p. 2). China, Netherlands and the United Kingdom are the only countries Ghana has BITs with out of the top ten countries investing in Ghana 
in 2010. Ghana does not have an investment treaty with the remaining seven countries including Israel, Trinidad and Tobago, Nigeria and India.

The conclusion that empirically follows from the data for 2008-2010 on investment inflows to Ghana is that Ghana's BITs have not led to more investment attraction from Ghana's contracting parties to BITs when compared with the countries with which it does not have BITs. On the contrary, the research shows that at one point investment had been made from only three contracting parties to BITs and even investments from those countries did not lead in terms of the number of registered projects or in terms of the value of the estimated projects. Thus, Ghana's BITs have not led to more investments from these countries. Most foreign investors investing in Ghana do not come from countries that have investment treaties with Ghana. The Ghanaian experience suggests then that without BITs a country can still attract foreign investment.

The 2011 and 2012 investment inflows to Ghana show a similar pattern as in 2008-2010. There were, in total, 514 projects registered in 2011, with a total estimated value of GHф11.52 billion (US\$7.68 billion) (GIPC 2012, p. 1). Initial capital transfers in relation to these projects amounted to GH $\notin 319.94$ million (US\$213.29 million). Out of the 514 registered projects over the period, 327 were wholly-owned foreign enterprises and 187 were joint ventures between Ghanaians and foreigners. While the joint venture projects were valued at GH $\$ 9.47$ billion (US\$6.31 billion), the whollyowned foreign projects were valued at GH $\phi 2.06$ billion (US $\$ 1.37$ billion) (GIPC 2012, p. 1). The FDI component of the estimated value of the projects registered in 2011 amounted to GH $\phi 10.23$ billion (US\$6.82 billion). China, as usual, topped the list of countries with seventy-nine projects registered while Korea topped the list of countries with the largest value of investments of US\$4.77 billion (GIPC 2012, p. 4). Over the period, most of the countries investing in Ghana such as India, South Africa, Korea, Nigeria and Lebanon did not have BITs with Ghana.

In 2012, the total number of projects registered was 399, with a total estimated value of GHф10.14 billion (US\$5.63 billion). The total initial capital transfers in relation to these projects amounted to $\mathrm{GH} \phi 178.15$ million (US\$98.97 million) in 2102. The FDI component of the estimated value of the projects registered over the period amounted to $\mathrm{GH} \notin 8.83$ billion (US $\$ 4.90$ billion). China topped the list of countries with the highest number of registered projects of 56 projects while Lebanon topped the list of countries with the largest FDI value amounting to US\$1.49 billion. The ten top countries making investment in Ghana in 2012 were China, India, Nigeria, Lebanon, Britain, Netherlands, United States, British Virgin Islands, 
Germany and Mauritius (GIPC 2013, p. 3). Only three of these countries had BITs with Ghana while the other seven countries did not. The Netherlands, a treaty partner of Ghana, topped the list of countries with the largest value of investments (US\$236.03 million FDI value) registered between October and December 2012 (GIPC 2013, p. 2). The GIPC Quarterly reports for 2017 also show that most of Ghana's FDIs continue to come from countries with which Ghana has no BITs (GIPC 2017).

Two conclusions can be drawn from these data. Ghana has been receiving most of its investments from countries with which it does not have BITs. The BITs cannot be singled out as the sole determinant of investment inflows from Ghana's contracting parties to BITs, or as playing any role at all. These two conclusions lead to the suggestion that while BITs may be important, their absence does not mean that Ghana will not be able to attract foreign investment.

The Ghanaian experience suggests that if BITs were relevant for the decision to invest in Ghana, then investors from countries with which Ghana has BITs should have been investing in Ghana more than countries with which it does not have BITs. Conversely, if BITs were paramount in the decision to invest in Ghana, then investors from countries with which Ghana does not have BITs should have been investing less or not all in Ghana. These arguments particularly hold in view of the fact that Ghana does not have special arrangements with its non-contracting parties to BITs to which investment inflows from these parties could be attributed.

The following Table shows the number of countries that made investments in Ghana from both contracting parties and non-contracting parties of Ghana to BITs from 2008 to 2012.

\begin{tabular}{|l|l|l|}
\hline Year & BIT Contracting Parties & Non-BIT Countries \\
\hline 2008 & 3 & 8 \\
\hline 2009 & 5 & 12 \\
\hline 2010 & 5 & 11 \\
\hline 2011 & 5 & 13 \\
\hline 2012 & 5 & 12 \\
\hline
\end{tabular}

Ghana placed third among the top five countries in Africa to receive investment inflows of above $\$ 3.0$ billion in 2010/2011. The other countries were Nigeria, South Africa, Congo and Algeria (UNCTAD 2012, p. 39). Most of these countries are natural resource-rich countries and the nature of their resources must have played a significant role in the investment inflows received (Botchway 2011). In the case of Ghana, apart from gold and other minerals, commercial production of oil started in December 2010. The flows 
of investment to West Africa in 2011 were primarily received in Ghana and Nigeria, which together accounted for some three quarters of the sub region's inflows. Again, both Ghana and Nigeria are endowed with petroleum resources. Ghana, 'in particular, benefited from FDI in the newly developed Jubilee oil field' (UNCTAD 2012, p. 40). Ghana was not, however, among the top five home countries for investment outflows in Africa in 2011 and 2012. This means investment outflows from Ghana are negligible. The low level of investment outflow from Ghana suggests that Ghanaians are investing less in foreign countries. The investment outflows from Ghana are not necessarily destined only to countries that Ghana has BITs with but to all countries, including African countries, with only one of which Ghana currently has a BIT in force.

The GIPC mandate is to promote investment in Ghana, whether by foreign investors or domestic investors rather than promoting the making of investment outside Ghana. The GIPC's quarterly reports basically provide information on investment inflows. In fact, the primary object of the Ghana Investment Promotion Centre Act 2013 (Act 865) is the encouragement and promotion of investment in the Ghanaian economy. By law, policy and practice, the focus of investment promotion then is the enhancement of an environment conducive for business in Ghana. There does not appear to be any emphasis being placed on encouraging Ghanaian business to invest in the territories of Ghana's contracting parties to BITs. This explains, at least in part, the low level of investment outflows from Ghana. So it cannot be concluded with certainty that the BITs of Ghana play any role in the decision of Ghanaians to make investments in the territories of Ghana's contracting parties to BITs.

Given the low and negligible levels of investment outflows out of Ghana and the focus of municipal investment law, policy and practice of encouraging investment in Ghana, international instruments intended to create favourable conditions for investment outside of Ghana seem misplaced. The BITs are intended to promote reciprocal investment in respective territories of their contracting parties. So in entering into a BIT, Ghana needs to take into consideration the extent to which its domestic investors are capable and willing to invest in the territories of Ghana's potential contracting parties to BITs. If reciprocal investment will not be made now or in the future by Ghanaian investors in the territory of the prospective contracting party to BIT, then some other legal mechanisms such as domestic investment laws and policies in the host country to provide protection for the investors from the country which will invest in Ghana should be relied on rather than BITs. 
Most of the BITs of Ghana came into force in the 1990s and given the infinitesimal nature of investment outflows from Ghana, it seems Ghana entered into BITs to promote diplomacy without satisfying itself that there was the need for those instruments for Ghana's investment abroad. This also points to the conclusion that Ghana's entry into these instruments would probably meet the needs of its contracting parties to BITs more than its national interest. It should also be noted that efforts toward concluding BITs in Ghana started in 1980s with the involvement of the World Bank with its structural adjustment program in Ghana (Poulsen 2015, pp. 99-102).

\section{Attracting Investments without BITS}

Tsikata, Asante and Gyasi (2000, p. 95) found that incentives, availability of raw materials and the nature of the market conditions were influential in attracting foreign direct investment to Ghana. They found that corporate tax reductions contributed to raising investor confidence in the economy and suggested that 'periodic rate reductions might constitute an appropriate longterm fiscal strategy for building up permanent investor confidence' (Tsikata, Asante \& Gyasi 2000, p. 99). Further, they found that the overall investment climate was very important in influencing foreign investment (Tsikata, Asante \& Gyasi 2000, p. 99). Indeed, the 'general investment climate is more crucial to investors than just the tax waivers as a key element in the incentive package' (Tsikata, Asante and Gyasi 2000, p. 65). They also found that dependence on domestic investment law to invest was significant but that that dependence derived mainly from incentives under the investment law (Tsikata, Asante \& Gyasi 2000, p. 65).

According to UNCTAD (2003, p. 3), in 1991-1995 Ghana 'was considered a front runner, ranking among the top 10 investment locations in Africa.' The increase in foreign investment 'was triggered by the adoption of policies in 1986 to attract investment in natural resources' including the enactment of legislation for the mining sector (UNCTAD 2003, p.4). The privatisation of state-owned enterprises, particularly the Ashanti Goldfields Corporation, also 'put Ghana in the spotlight for international investment' (UNCTAD 2003, p. 4). Mmieh and Owusu-Frimpong (2004) also attributed investment inflows to Ghana to structural adjustment reforms and domestic legislative reforms. Other factors that may help investment inflows into Ghana include the establishment of a regulatory framework governing privatisation, improvement in internal economic management, and regional integration (UNCTAD 2003, p. 6). Investors are also 'attracted by Ghana's wealth of gold, aluminium, bauxite, timber, diamonds, manganese, and oil and natural gas exploration' (UNCTAD 2003, p. 6). 
According to UNCTAD (2003), Ghana still has the potential to be the front-runner in Africa for foreign direct investment. However, if this is to be achieved, there is a need overall to improve economic performance because '[m]acroeconomic instability, weak infrastructure, low productivity and lack of business partners, all deter FDI' (p. 77). Further, a number of wide-ranging actions are needed to restore investor confidence, including a sound investment framework that provides for non-discriminatory treatment and guarantees to foreign investors, programs to revive investment by domestic and established foreign investors, development of the entrepreneurial skills of Ghanaian businesses, development of the human resource and technology policies, and the consolidation or coordination of the various institutions responsible for investment promotion and protection (UNCTAD 2003, pp. 77-80).

The conclusion from the foregoing is that no single factor, including investment treaties, can be credited for the level of investment inflows into Ghana. While investment treaties may provide some legal security to foreign investors and may thereby influence their decision to invest abroad, these treaties only form part of a complex of other factors that influence such decisions. Indeed, Ghana's front-runner status as an investment destination in Africa was short-lived since after 1996, at a time when Ghana's BITs came into force; investment inflows declined with Ghana barely ranking in the top twenty foreign direct investment recipient in Africa in 1996-2000 (UNCTAD 2003, p. 5). Thus, standing alone, BITs cannot attract FDI. Government should not unreasonably limit its power to regulate in the public interest through investment treaties since they do not play any outstanding or significant role in investment attraction.

These findings on the overall factors that determine FDI in Ghana support the proposition that investors from Ghana's non-contracting parties to BITs made investments because of the overall socio-political, economic and domestic legal environment for business in Ghana. In other words, if BITs were an overriding factor in the decision to invest in Ghana, then investors from countries that do not have investment treaties with Ghana would not make investments in Ghana. The findings of Tsikata and others about the determinants of foreign investment in Ghana were silent on the specific role of BITs as sources of investment attraction, although they were clear about the role of domestic investment law.

The analysis above supports Rose-Ackerman's view that BITs cannot have a positive role on FDI flows except 'only in interaction with the political and economic environment for development' (Rose-Ackerman 2009, p. 321). The conclusion from the GIPC quarterly reports is that Ghana can attract 
foreign investment even in the absence of BITs. Factors and motives other than BITs can influence the decision to invest abroad.

\section{Conclusion}

Experience in Ghana suggests that a variety of factors determine the inflow of foreign investment into a country, not just a single factor, and that BITs do not make any unique or singular contribution. Current evidence of the link between investment treaties and investment flows to Ghana supports the proposition advanced by UNCTAD (2003, p. ii) that '[s]imply opening up to foreign investment does not guarantee inflows'. It is, therefore, important not to place too much emphasis on one particular isolated factor, including BITs, as a determinant of foreign investment inflows to Ghana. The findings suggest that the role of BITs as determinants of foreign investment in Ghana will have to be judged against the fact that Ghana has been attracting large investments by investors from countries with which Ghana does not have BITs. Importantly, the findings suggest that attracting investment through BITs is illusory and that limiting the right to regulate in the public interest under the BITs is unjustifiable. As investment treaties are not the only determinants of foreign investment attraction to Ghana, the government must not restrict its right to regulate for the protection of the public interest.

Ghana needs to rethink the relevance of BITs in creating favourable conditions for investment and in attracting foreign investment against the limitations they place on its right to regulate in the public interest. In particular, as investments in quantity and value are made in Ghana from countries with which it does not have BITs, the issue whether Ghana needs BITs at all arises. It would be sufficient for Ghana to provide the necessary and reliable municipal legal and institutional framework to protect legitimate investment and to create the social, economic and political environment that enhanced business for both foreign and domestic investors. As UNCTDAD argues, BITs alone,

cannot turn a bad domestic investment climate into a good one and they cannot guarantee the inflow of foreign investment. There is no mono-causal link between the conclusion of an IIA and FDI inflows; IIAs play a complementary role among many determinants that drive firms' investment decisions. Most important, IIAs cannot be a substitute for domestic policies and a sound national regulatory framework for investment (2003, pp. 133). 


\section{References}

Aisbett, E. (2009). Bilateral Investment Treaties and Foreign Direct Investment: Correlation versus Causation. In Sauvant, K. P. and Sachs, L. E. (Eds), The Effect of Treaties on Foreign Direct Investment: Bilateral Investment Treaties, Double Taxation Treaties, and Investment Flows, (pp. 395-437). New York. Oxford University Press.

Asiedu, E. (2002). On the Determinants of Foreign Direct Investment to Developing Countries: Is Africa Different? World Development, 30(1), 107-119.

Berger, A., Busse, M., Nunnenkamp, P. and Roy, M. (2013). Do Trade and Investment

Agreements Lead to More FDI? Accounting for Key Provisions inside the Black Box. International Economic Policy, 10, 247-275

Botchway, F. N. (2011). Natural Resource Investment and Africa's Development. Edward Elgar.

Buthe, T. and Milner, H. V. (2009). Bilateral Investment Treaties and Foreign Direct

Investment: A Political Analysis. In Sauvant, K. P. and Sachs, L. E. (Eds), The Effect of Treaties on Foreign Direct Investment: Bilateral Investment Treaties, Double Taxation Treaties, and Investment Flows, (pp. 171-224.). New York. Oxford University Press.

Dagbanja, D. N. (2015). The Investment Treaty Regime and Public Interest Regulation in Ghana: Perspectives in Constitutionalism and General International Law (PhD Dissertation, University of Auckland).

Dunning, J. H. (1994). Re-evaluating the Benefits of Foreign Direct Investment. Transnational Corporations, 3(1), 23-52.

Economic Commission for Africa. (2016). Investment Policies and Bilateral Investment Treaties in Africa: Implications for Regional Integration. United Nations.

Egger, P. and Pfaffermayr, M. (2004). The Impact of Bilateral Investment Treaties on

Foreign Direct Investment. Journal of Comparative Economics, 32(4), 788804

Feris, J. (2015). "Challenging the Status Quo - South Africa's Termination of its Bilateral Trade Agreements" International Arbitration Newsletter (10 December),

Ghana Investment Promotion Centre. (2017). Quarterly Investment Report, 13(4).

(2017). GIPC Fourth Quarterly Report, 13(3).

(2017). GIPC Fourth Quarterly Report, 13(2). 
(2017). GIPC Fourth Quarterly Report, 13(1). (January 2013). The GIPC Fourth Quarterly Update 8(4). (January 2012). The GIPC Quarterly Update, 7(4). (January 2011). The GIPC Quarterly Update, 6(4). (January 2010). The GIPC Quarterly Update, 5(4). (January, 2009). The GIPC Quarterly Update, 4(4).

Hallward-Driemeier, M. (2009). Do Bilateral Investment Treaties Attract FDI,? Only a Bit ... and They Could Bite in BITs. In Sauvant, K. P. and Sachs, L. E. (Eds). The Effect of Treaties on Foreign Direct Investment: Bilateral Investment Treaties, Double Taxation Treaties, and Investment Inflows (pp. 350-378). Oxford University Press.

Harten, G. V. (2008). Investment Treaty Arbitration and Its Policy Implications for Capital-Importing States. In D Sánchez-Ancochea, D. and Shadlen, K. C. (Eds). The Political Economy of Hemispheric Integration: Responding to Globalization in the Americas (pp 83112). Palgrave Macmillan.

(2007). Investment Treaty Arbitration and Public Law. Oxford University Press

Kelsey, J. (2012). International Trade and Tobacco Control: Trade and Investment Law Issues Relating to Proposed Tobacco Control Policies to Achieve an Essentially Smokefree Aotearoa New Zealand by 2025. Tobacco Control Research Turanga.

(2010). How the Trans-Pacific Partnership Agreement Could Heighten Financial Instability and Foreclose Governments' Regulatory Autonomy. New Zealand Yearbook of International Law, $8,3-44$.

Kerner, A. (2009). Why Should I Believe You? The Costs and Consequences of Bilateral Investment Treaties. International Studies Quarterly, 53, 73-102.

Mmieh, F. and Owusu-Frimpong, N. (2004). State Policies and the Challenges in Attracting Foreign Direct Investment: A Review of the Ghana Experience. Thunderbird International Business Review, 46(5), 575-599.

Muchlinski, P. (2007). Multinational Enterprises and the Law ( $2^{\text {nd }}$ ed). Oxford University Press

Neumayer, E. and Spess, L. (2005). Do Bilateral Investment Treaties Increase Foreign Direct Investment to Developing Countries? World Development, 33(10), 567-1585 
Poulsen, L. N. S. (2015). Bounded Rationality and Economic Diplomacy: The Politics of Investment Treaties in Developing Countries. Cambridge University Press.

Poulsen, L. N. S. (2010). The Importance of BITs for Foreign Direct Investment and Political Risk Insurance: Revisiting the Evidence. In Sauvant, K. P. (Ed). Yearbook on International Investment Law and Policy 2009/2010, (pp. 539-574). New York. Oxford University Press. Rose-Ackerman, S. and Tobin, J. L. (2009). Do BITs Benefit Developing Countries? In Rogers, C. A. and Alford R. P. (Eds). The Future of Investment Arbitration (pp. 131-144). Oxford University Press.

Rose-Ackerman, S. (2009). The Gobal BITs Regime and the Domestic Environment for Investment. In Sauvant, K. P. and Sachs, L. E. (Eds). The Effect of Treaties on Foreign Direct Investment: Bilateral Investment Treaties, Double Taxation Treaties, and Investment Inflows, (pp 312-322). Oxford University Press.

Salacuse, J. and Sullivan, N. (2005). Do BITs Really Work? An Evaluation of Bilateral Investment Treaties and Their Grand Bargain. Harvard International Law Journal, 46, 67-130.

Schneiderman, D. (2008). Constitutionalizing Economic Globalization: Investment Rules and Democracy's Promise (Cambridge University Press.

Sornarajah, M. (2010). The International Law on Foreign Investment ( $\left.3^{\text {rd }} \mathrm{ed}\right)$. Cambridge University Press.

Swenson, D . L. (2009). Why Do Developing Countries Sign BITs. In Sauvant, K. P. and Sachs, L. E. (Eds). The Effect of Treaties on Foreign Direct Investment: Bilateral Investment Treaties, Double Taxation Treaties, and Investment Inflows (pp. 437-457). Oxford University Press.

Tsikata, G.K., Asante, Y., and Gyasi, E. M. (2000). Determinants of Foreign Direct Investment in Ghana. Overseas Publication Institute.

United Nations Conference on Trade and Development. (2018). World Investment Report 2018: Investment and New Industrial Policies. New York and Geneva: United Nations.

(2012). World Investment Report 2012: Towards a New Generation of Investment Policies. United Nations.

(2003a). Investment Policy Review: Ghana. United Nations.

(2003b). The Development Dimension of FDI: Policy and Rule-Making Perspectives. United Nations. 
Waibel, M., Kaushal A., Chung, K. and Balchin, C. (Eds.). (2010). The Backlash against Investment Arbitration: Perceptions and Reality. Kluwer Law International.

World Bank (1966). Convention on the Settlement of Investment Disputes between States and Nationals of Other States.

Yackee, J. W. (2009). Do BITs Really Work? Revisiting the Empirical Link between Investment Treaties and Foreign Direct Investment. In Sauvant, K. P. and Sachs, L. E. (Eds). The Effect of Treaties on Foreign Direct Investment: Bilateral Investment Treaties, Double Taxation Treaties, and Investment Inflows (pp. 379-394). Oxford University Press.

(2008). Bilateral Investment Treaties, Credible Commitment, and the Rule of (International) Law: Do BITs Promote Foreign Direct Investment? Law and Society Review, 42(4), 805-832

Yelpaala, K. (1984). The Efficacy of Tax Incentives within the Framework of the Neoclassical Theory of Foreign Direct Investment: A Legislative Policy Analysis. Texas International Law Journal, 19, 365-414

(1985). In Search for Effective Policies for Foreign Direct Investment: Alternatives to Tax Incentive Policies. Northwestern Journal of International Law and Business, 7(2), 208 - 266. 